\title{
Pengaruh Rasio Profitabilitas Terhadap Nilai Perusahaan Pada Industri Minyak dan Gas Bumi yang Terdaftar di Bursa Efek Indonesia Periode 2012 - 2016
}

\author{
Venny Junica Utami \\ Fakultas Ekonomi, Universitas Batanghari
}

The research object of the research is Oil and Gas Industry and obsrvation object from 2012 -2016 where the sample consist of 4 companies namely PT. Ratu Prabu Energi Tbk, PT. Elnusa Tbk, PT. Surya Esa Perkasa Tbk, and PT. Radiant Utama Interinsco Tbk. Based on result of research assisted by software SPSS 20 generated regression equation $Y=-2,296 \times 10^{-11}+0,055 X_{1}-0,100 X_{2}+0,641 X_{3}+e$ on the other side obtained simultane ously test independent variable (profitability ratio) have significant effect to dependent variable (Value of the Company) marked with Fhitung 4,149 > $F_{\text {tabel }}$ 3,24, for independent and partially dependent influence that return on asset and return on equity not a significant effect to Value of the Company, while net profit margin has a significant effect to Value of the Company. The independent variable (profitability ratio) is able to influence the dependent variable (Value of the Company). Rated $R$ Square 43,8\%, while the remaining 56,2\% explained other factors beyond the study models.

Key Word: Net Profit Margin, Return on Asset, Return on Equity

\section{PENDAHULUAN}

Laporan keuangan merupakan salah satu sumber informasi keuangan yang diterbitkan perusahaan kepada publik yang menunjukkan kondisi keuangan perusahaan pada saat ini atau suatu periode tertentu. Memahami laporan keuangan perlu dianalisa terlebih dahulu dengan menggunakan analisis laporan keuangan. Analisis laporan keuangan biasanya menggunakan analisis rasio keuangan. Rasio keuangan menurut Fahmi (2016:49), suatu kajian yang melihat perbandingan antara jumlah-jumlah yang terdapat pada laporan keuangan dengan mempergunakan formulaformula yang dianggap representatif untuk diterapkan. Rasio keuangan merupakan suatu perhitungan rasio dengan menggunakan laporan keuangan yang berfungsi sebagai alat ukur dalam menilai kondisi keuangan dan kinerja perusahaan. Umumnya rasio keuangan dikelompokkan menjadi lima yaitu: rasio likuiditas, rasio solvabilitas, rasio aktivitas, rasio profitabilitas, dan rasio nilai pasar. Menurut Fahmi (2016:49), rasio profitabilitas merupakan rasio yang menggambarkan kemampuan perusahaan dalam menghasilkan laba. Rasio ini dapat dibedakan menjadi dua jenis, yaitu Rasio Tingkat Pengembalian atas Investasi dan Rasio Kinerja Operasi. Rasio profitabilitas yang digunakan dalam penelitian ini adalah Return On Assets (ROA), rasio ini digunakan untuk mengukur seberapa besar jumlah laba bersih yang akan dihasilkan dari setiap rupiah dana yang tertanam dalam total aset. Return On Equity (ROE), rasio ini digunakan untuk mengukur seberapa besar jumlah laba bersih yang akan dihasilkan dari setiap rupiah dana yang tertanam dalam total ekuitas. Net Profit Margin $(N P M)$, rasio ini digunakan untuk 
mengukur besarnya persentase laba bersih atas penjualan bersih.

Menurut Dewanto (2017:3), nilai perusahaan merupakan persepsi investor terhadap perusahaan, yang sering dikaitkan dengan harga saham. Harga saham yang cukup tinggi akan memberikan keuntungan, yaitu berupa capital gain dan citra yang lebih baik bagi perusahaan sehingga memudahkan bagi manajemen untuk mendapatkan dana dari luar perusahaan. Nilai perusahaan merupakan harga yang bersedia dibayar oleh pembeli apabila saham perusahaan tersebut dijual. Mengukur nilai perusahaan dapat dilihat dari harga sahamnya. Hal ini sesuai dengan Husnan dan Pudjiastuti (2004:210) ia mengatakan bahwa, Bagi perusahaan yang menerbitkan saham di pasar modal, harga saham yang diperjual belikan di bursa merupakan indikator nilai perusahaan". Harga saham merupakan harga yang terjadi pada saat saham diperdagangkan di pasar modal. Menurut Fahmi (2016:270), ada tiga definisi saham yaitu: (1). Saham adalah tanda bukti penyertaan kepemilikan modal atau dana pada suatu perusahaan, (2). Saham adalah kertas yang tercantum dengan jelas nilai nominal, nama perusahaan dan diikuti dengan hak dan kewajiban yang dijelaskan kepada setiap pemegangnya, (3). Saham adalah persediaan yang siap untuk dijual. Jika ditinjau dari sudut pandang perusahaan (emiten) saham merupakan alternatif surat berharga yang bisa dipakai oleh perusahaan untuk mendapatkan dana segar dari masyarakaat (investor). Sedangkan jika ditinjau dari sudut pandang masyarakat (investor) yang menginvestasikan dananya pada saham, saham merupakan surat berharga yang memberikan hak kepemilikan aset-aset perusahaan yaitu hak untuk memperoleh dividen dan capital gain. Saham ada dua macam yaitu saham biasa dan saham preferen. Saham perusahaan yang go public merupakan komoditi investasi yang tergolong berisiko tinggi, karena sifat komoditinya sangat peka terhadap perubahan-perubahan yang terjadi, baik perubahan di luar negeri atau perubahan di dalam negeri.

Penelitian ini dilakukan untuk meneliti kembali pengaruh rasio profitabilitas terhadap nilai perusahaan, dimana menurut peneliti rasio profitabilitas sebelumnya yaitu, Ningrum (2016:7), menyatakan bahwa profitabilitas berpengaruh terhadap nilai perusahaan pada perusahaan BUMS yang terdaftar di Bursa Efek Indonesia (BEI) tahun 2009 - 2013. Sedangkan penelitian yang dilakukan oleh Novianto (2016:106), menyatakan bahwa profitabilitas tidak mempunyai pengaruh yang signifikan dan positif terhadap nilai perusahaan manufaktur yang terdaftar di Bursa Efek Indonesia (BEI) tahun 2010 - 2014. Ketidak konsistenan inilah memberikan motivasi bagi peneliti untuk meneliti kembali pengaruh rasio profitabilitas terhadap nilai perusahaan pada perusahaan dan waktu yang berbeda. Perusahaan yang digunakan dalam penelitian ini adalah industri minyak dan gas bumi yang terdaftar di Bursa Efek Indonesia (BEI) tahun 2012 2016.

Industri Minyak dan Gas Bumi merupakan sektor penting di dalam pembangunan nasional baik dalam hal pemenuhan kebutuhan energi dan bahan baku industri di dalam negeri maupun sebagai penghasil devisa negara sehingga pengelolaannya perlu dilakukan seoptimal mungkin. Industri Minyak dan Gas Bumi merupakan sub 
sektor dari perusahaan pertambangan yang tercatat di Indonesia. Pada Bursa Efek Indonesia ada 9 (sembilan) perusahaan yang termasuk dalam industri minyak dan gas bumi, dari 9 (sembilan) perusahaan hanya 4 (empat) perusahaan yang menjadi sampel dalam penelitian ini yaitu : PT Ratu Prabu Energi Tbk (ARTI), PT
Elnusa Tbk (ELSA), PT Surya Esa Perkasa Tbk (ESSA), dan PT Radiant Utama Interinsco Tbk (RUIS). Perkembangan dan rata-rata Return On Assets, Return On Equity, Net Profit Margin, dan data nilai perusahaan yaitu harga saham saat penutupan (closing price), dapat dilihat dalam tabel 1.1, 1.2, 1.3, dan 1.4 dibawah ini:

Tabel 1

Data Return On Asset (ROA) Pada Industri Minyak Dan Gas Bumi Yang Terdaftar Di Bursa Efek Indonesia Periode 2012 - 2016

\begin{tabular}{|c|c|c|c|c|c|c|c|}
\hline \multirow{2}{*}{ No } & \multirow{2}{*}{ Nama Perusahaan } & \multicolumn{5}{|c|}{ Return On Assets (ROA) \% } & \multirow{2}{*}{ Rerata } \\
\hline & & 2012 & 2013 & 2014 & 2015 & 2016 & \\
\hline 1 & Ratu Prabu Ene & 3,62 & 4,21 & 1,70 & 0,73 & 0,35 & 2,12 \\
\hline 2 & Elnusa Tbk & 3,16 & 5,55 & 9,85 & 8,62 & 7,54 & 6,94 \\
\hline 3 & Surya Esa Perkasa Tbk & 6,44 & 10,63 & 7,38 & 1,75 & 0,02 & 5,24 \\
\hline 4 & $\begin{array}{l}\text { Radiant Utama Interinsco } \\
\text { Tbk }\end{array}$ & 2,46 & 2 & 4,41 & 3,78 & 2,66 & 3,13 \\
\hline \multicolumn{2}{|c|}{ Jumlah } & 15,68 & 22,71 & 23,34 & 14,88 & 10,57 & 17,44 \\
\hline \multicolumn{2}{|c|}{ Tertinggi } & 6,44 & 10,63 & 9,85 & 8,62 & 7,54 & 8,62 \\
\hline \multicolumn{2}{|c|}{ Terendah } & 2,46 & 2,32 & 1,70 & 0,73 & 0,02 & 1,45 \\
\hline \multicolumn{2}{|c|}{ Rata-Rata Industri } & 3,92 & 5,68 & 5,84 & 3,72 & 2,64 & 4,36 \\
\hline \multicolumn{2}{|c|}{ Perkembangan } & _- & 0,45 & 0,03 & $-0,36$ & $-0,29$ & $-0,04$ \\
\hline
\end{tabular}

Sumber: Bursa Efek Indonesia dan Data Diolah

Berdasarkan Tabel 1 mengenai Return On Asset (ROA) pada industri minyak dan gas bumi yang terdaftar di Bursa Efek Indonesia selama periode 2012 - 2016, dapat dilihat nilai perkembangan yang cenderung mengalami penurunan. Dengan nilai perkembangan tertinggi terdapat pada tahun 2013 dengan persentase $0,45 \%$, sedangkan nilai perkembangan terendah pada tahun 2015 dengan nilai minus $0,36 \%$. Rata-rata industri tertinggi pada tahun 2014 yaitu $5,84 \%$, dengan nilai perkembangan $0,03 \%$. Sedangkan rata-rata industri terendah terjadi pada tahun 2016 yaitu $2.64 \%$, dengan nilai perkembangan minus 0,29\%. Berikut ini akan disajikan hasil perhitungan Return On Equity dapat dilihat pada Tabel 2 dibawah ini.

Tabel 2

Data Return On Equity (ROE) Pada Industri Minyak Dan Gas Bumi Yang Terdaftar Di Bursa Efek IndonesiaPeriode 2012 - 2016

\begin{tabular}{|c|c|c|c|c|c|c|c|}
\hline \multirow{2}{*}{ No } & \multirow{2}{*}{ Nama Perusahaan } & \multicolumn{5}{|c|}{ Return On Equity (ROE) \% } & \multirow{2}{*}{ Rerata } \\
\hline & & 2012 & 2013 & 2014 & 2015 & 2016 & \\
\hline 1 & Ratu Prabu Energi Tbk & 6,06 & 7,16 & 3,11 & 1,06 & 0,53 & 3,58 \\
\hline 2 & Elnusa Tbk & 6,64 & 10,62 & 16,19 & 14,41 & 10,98 & 11,77 \\
\hline 3 & Surya Esa Perkasa Tbk & 10,07 & 13,98 & 10,29 & 2,66 & 0,07 & 7,41 \\
\hline
\end{tabular}




\begin{tabular}{lrrrrrr}
$4 \quad$ Radiant Utama Interinsco Tbk & 12,19 & 11,32 & 17,94 & 12,20 & 7,25 & 12,18 \\
Jumlah & 34,96 & 43,08 & 47,53 & 30,33 & 18,83 & 34,95 \\
Tertinggi & 12,19 & 13,98 & 17,94 & 14,41 & 10,98 & 13,90 \\
Terendah & 6,06 & 7,16 & 3,11 & 1,06 & 0,07 & 3,49 \\
Rata-Rata Industri & 8,74 & 10,77 & 11,88 & 7,58 & 4,71 & 8,74 \\
Perkembangan & & 0,23 & 0,10 & $-0,36$ & $-0,38$ & $-0,10$ \\
\hline
\end{tabular}

Sumber: Bursa Efek Indonesia dan Data Diolah

Berdasarkan Tabel 2 diatas mengenai Return On Equity (ROE) pada industri minyak dan gas bumi yang terdaftar di Bursa Efek Indonesia selama periode 2012 - 2016, dapat dilihat nilai perkembangan yang menurun setiap tahunnya. Dengan nilai perkembangan tertinggi terdapat pada tahun 2013 dengan persentase 0,23\%, sedangkan nilai perkembangan terendah pada tahun 2016 dengan nilai minus $0,38 \%$. Rata-rata industri tertinggi pada tahun 2014 yaitu $11,88 \%$, dengan nilai perkembangan $0,10 \%$. Sedangkan rata-rata industri terendah terjadi pada tahun 2016 yaitu $4,71 \%$, dengan nilai perkembangan minus $0,38 \%$. Hasil perhitungan $\mathrm{Net}$ Profit Margin dapat dilihat pada Tabel 3 dibawah ini.

Tabel 3

\section{Data Net Profit Margin (NPM) Pada Industri Minyak Dan Gas Bumi Yang} Terdaftar Di Bursa Efek IndonesiaPeriode 2012 - 2016

\begin{tabular}{|c|c|c|c|c|c|c|c|}
\hline \multirow{2}{*}{ No } & \multirow{2}{*}{ Nama Perusahaan } & \multicolumn{5}{|c|}{ Net Profit Margin (NPM) \% } & \multirow{2}{*}{ Rerata } \\
\hline & & 2012 & 2013 & 2014 & 2015 & 2016 & \\
\hline 1 & Ratu Prabu Energi Tbk & 11,54 & 16,42 & 8,41 & 7,88 & 4,39 & 9,73 \\
\hline 2 & Elnusa Tbk & 2,84 & 5,90 & 9,90 & 10,06 & 8,73 & 7,49 \\
\hline 3 & Surya Esa Perkasa Tbk & 13,19 & 29,76 & 25,84 & 12,03 & 0,53 & 16,27 \\
\hline 4 & Radiant Utama Interinsco Tbk & 1,81 & 1,65 & 3,04 & 2,58 & 1,98 & 2,21 \\
\hline \multicolumn{2}{|c|}{ Jumlah } & 29,38 & 53,73 & 47,19 & 32,55 & 15,63 & 35,70 \\
\hline \multicolumn{2}{|c|}{ Tertinggi } & 13,19 & 29,76 & 25,84 & 12,03 & 8,73 & 17,91 \\
\hline \multicolumn{2}{|c|}{ Terendah } & 1,81 & 1,65 & 3,04 & 2,58 & 0,53 & 1,92 \\
\hline \multicolumn{2}{|c|}{ Rata-Rata Industri } & 7,35 & 13,43 & 11,80 & 8,14 & 3,91 & 8,92 \\
\hline \multicolumn{2}{|c|}{ Perkembangan } & - & 0,83 & $-0,12$ & $-0,31$ & $-0,52$ & $-0,03$ \\
\hline
\end{tabular}

Sumber: Bursa Efek Indonesia dan Data Diolah

Berdasarkan Tabel 3 diatas mengenai Net Profit Margin (NPM) pada industri minyak dan gas bumi yang terdaftar di Bursa Efek Indonesia selama periode 2012 - 2016, dapat dilihat nilai perkembangan yang menurun setiap tahunnya. Dengan nilai perkembangan tertinggi terdapat pada tahun 2013 dengan persentase 0,83\%, sedangkan nilai perkembangan terendah pada tahun 2016 dengan nilai minus $0,52 \%$. Rata-rata industri tertinggi pada tahun 2013 yaitu $13,43 \%$, dengan nilai perkembangan $0,83 \%$. Sedangkan rata-rata industri terendah terjadi pada tahun 2016 yaitu $3,91 \%$, dengan nilai perkembangan minus $0,52 \%$. Data nilai perusahaan yang diproksi dari harga saham yaitu Closing Price dapat dilihat pada Tabel 4 dibawah ini. 
Tabel 4

Data Nilai Perusahaan Industri Minyak Dan Gas Bumi Yang Terdaftar Di Bursa Efek Indonesia Periode 2012 - 2016

\begin{tabular}{|c|c|c|c|c|c|c|c|}
\hline \multirow{2}{*}{ No } & \multirow{2}{*}{ Nama Perusahaan } & \multicolumn{5}{|c|}{ Closing Price } & \multirow{2}{*}{ Rerata } \\
\hline & & 2012 & 2013 & 2014 & 2015 & 2016 & \\
\hline 1 & Ratu Prabu Energi Tbk & 260 & 181 & 101 & 170 & 50 & 152,4 \\
\hline 2 & Elnusa Tbk & 173 & 330 & 685 & 247 & 420 & 371 \\
\hline 3 & Surya Esa Perkasa Tbk & 3100 & 2375 & 2995 & 1650 & 1620 & 2348 \\
\hline 4 & Radiant Utama Interinsco Tbk & 195 & 192 & 217 & 215 & 236 & 211 \\
\hline \multicolumn{2}{|c|}{ Jumlah } & 3728 & 3078 & 3998 & 2282 & 2326 & 3082,4 \\
\hline \multicolumn{2}{|c|}{ Tertinggi } & 3100 & 2375 & 2995 & 1650 & 1620 & 2348 \\
\hline \multicolumn{2}{|c|}{ Terendah } & 173 & 181 & 101 & 170 & 50 & 135 \\
\hline \multicolumn{2}{|c|}{ Rata-Rata Industri } & 932 & 769,5 & 999,5 & 570,5 & 581,5 & 770,6 \\
\hline \multicolumn{2}{|c|}{ Perkembangan } & & $-0,17$ & 0,30 & $-0,43$ & 0,02 & $-0,07$ \\
\hline
\end{tabular}

Sumber: Bursa Efek Indonesia dan Data Diolah

Berdasarkan Tabel 4 diatas dapat dilihat nilai perkembangan yang berfluktuasi namun cenderung mengalami peningkatan. Dengan nilai perkembangan tertinggi terdapat pada tahun 2014 dengan persentase $0,30 \%$, sedangkan nilai perkembangan terendah pada tahun 2015 dengan nilai minus $0,43 \%$. Rata-rata industri tertinggi pada tahun 2014 yaitu $999,5 \%$, dengan nilai perkembangan $0,30 \%$. Sedangkan rata-rata industri terendah terjadi pada tahun 2015 yaitu $570,5 \%$, dengan nilai perkembangan minus $0,43 \%$. Dapat dilihat pada tabel diatas perusahaan Surya Esa Perkasa Tbk memiliki nilai rerata tertinggi yaitu $2348 \%$, sedangkan perusahaan dengan nilai rerata terendah yaitu Ratu Prabu Energi Tbk dengan nilai $152,4 \%$. Harga saham yang tinggi membuat nilai perusahaan juga tinggi, begitupun sebaliknya. Tingginya nilai perusahaan akan menarik minat investor untuk berinvestasi di perusahaan tersebut.

\section{METODE}

Metode penelitian yang akan digunakan dalam penelitian ini adalah menggunakan penelitian kuantitatif. Metode kuantitatif menurut Istijanto (2009:46) adalah metode yang digunakan untuk menganalisis data keuangan perusahaan dengan cara membandingkan laba rugi perusahaan serta menghitung tendensi perubahan yang terjadi. Jenis data yang digunakan dalam penelitian ini adalah data sekunder. Menurut Syekh (2011:5), data sekunder adalah data yang diperoleh atau dikumpulkan oleh orang yang melakukan penelitian dari sumber-sumber yang telah ada. Dalam Penelitian ini data diperoleh dari situs www.idx.co.id, literatur-literatur yang berkaitan dengan penelitian ini, dan hasil penelitian terdahulu yang relevansi dengan penelitian ini.Metode pengumpulan data dalam penelitian ini menggunakan metode penelusuran literatur. Menurut Syekh (2011 : 9), penelusuran literatur adalah cara pengumpulan data dengan menggunakan sebagian atau seluruh data yang ada atau laporan data dari peneliti sebelumnya. Penelusuran 
literatur disebut juga pengamatan tidak langsung.

Populasi dalam penelitian ini adalah seluruh perusahaan yang termasuk dalam industri minyak dan gas bumi yang go public di Indonesia yang terdaftar di Bursa Efek Indonesia (BEI) pada tahun 2012 - 2016. Untuk mengambil dari sejumlah sampel dari populasi digunakan teknik sampling yaitu purposive sample. Menurut Syekh (2011:16), purposive sample yaitu pengambilan sampel didasarkan atas ciri-ciri atau sifat-sifat tertentu yang dipandang mempunyai sangkut paut yang erat dengan ciri-ciri atau sifat-sifat populasi yang sudah diketahui sebelumnya. Dengan tujuan untuk mendapatkan sampel yang refresentatif atas kriteria yang telah ditentukan. Kriteria-kriteria tersebut adalah sebagai berikut: (1) Emitenemiten yang terdaftar di Bursa Efek Indonesia (BEI) selama periode 2012 2016; (2) Emiten-emiten yang tergabung dalam industri minyak dan gas bumi selama penelitian periode
2012 - 2016; (3) Emiten-emiten harus memiliki laporan keuangan yang mencantumkan nilai variabel-variabel yang akan diteliti periode 2012 - 2016; dan (4) Emiten-emiten dengan nilai variabel-variabel positif yang akan diteliti. Berdasarkan kriteria-kriteria dalam teknik sampling yang diuraikan diatas maka sampel dalam penelitian berjumlah 4 emiten. Berikut daftar emiten-emiten yang dijadikan sample pada penelitian sebagai berikut: PT Ratu Prabu Energi Tbk (ARTI); PT Elnusa Tbk (ELSA); PT Surya Esa Perkasa Tbk (ESSA); dan PT Radiant Utama Interinsco Tbk (RUIS)

\section{Operasional Variabel}

Operasional

variabel merupakan definisi atau uraian-uraian yang menjelaskan dari suatu variabelvariabel yang akan diteliti dan mencakup indikator- indikator yang ada pada masing-masing variabel. Operasional variabel dalam penelitian ini adalah sebagai berikut :

Tabel 5

Operasional Variabel

\begin{tabular}{|c|c|c|c|c|}
\hline Variabel & Konsep & Rumus & Satuan & Skala \\
\hline $\begin{array}{l}\text { Return On } \\
\text { Asset } \\
\left(\mathrm{X}_{1}\right)\end{array}$ & $\begin{array}{l}\text { Menurut Riyanto (2008:336), return on asset } \\
\text { merupakan kemampuan dari modal yang } \\
\text { diinvestasikan dalam keseluruhan aktiva untuk } \\
\text { menghasilkaan keuntungan neto. }\end{array}$ & $\frac{\text { Laba Bersih }}{\text { Total Aktiva }} \times 100 \%$ & $\%$ & Rasio \\
\hline $\begin{array}{l}\text { Return On } \\
\text { Equity } \\
\left(\mathrm{X}_{2}\right)\end{array}$ & $\begin{array}{l}\text { Menurut Novianto (2016:94), return on equity } \\
\text { digunakan untuk mengukur profitabilitas dari } \\
\text { ekuitas. }\end{array}$ & $\frac{\text { Laba Bersih }}{\text { Total Ekuitas }} \times 100 \%$ & $\%$ & Rasio \\
\hline $\begin{array}{l}\text { Net Profit } \\
\text { Margin } \\
\left(\mathrm{X}_{3}\right)\end{array}$ & $\begin{array}{l}\text { Menurut Bastian dan Suhardjono (2006:299), net } \\
\text { profit margin adalah perbandingan antara laba } \\
\text { bersih dengan penjualan bersih. }\end{array}$ & $\frac{\text { Laba Bersih }}{\text { Penjualan Bersih }} \times 100 \%$ & $\%$ & Rasio \\
\hline $\begin{array}{l}\text { Nilai } \\
\text { Perusahaan } \\
\text { (Y) }\end{array}$ & $\begin{array}{l}\text { Menurut Dewanto (2017:3), nilai perusahaan } \\
\text { merupakan persepsi investor terhadap perusahaan, } \\
\text { yang sering dikaitkan dengan harga saham. Harga } \\
\text { saham yang tinggi membuat nilai perusahaan juga } \\
\text { tinggi. }\end{array}$ & Closing Price & $\mathrm{Rp}$ & Nominal \\
\hline
\end{tabular}

HASIL

peneliti akan menganalisis data yang telah terkumpul, data yang sudah 
terkumpul tersebut berupa laporan keuangan yang ada pada industri minyak dan gas bumi periode 2012 2016, dimana variabel yang digunakan dalam penelitian ini, ada tiga variabel yaitu Return On Asset $\left(\mathrm{X}_{1}\right)$, Return On Equity $\left(\mathrm{X}_{2}\right)$, dan Net Profit Margin $\left(\mathrm{X}_{3}\right)$ sebagai variabel independen sedangkan Nilai Perusahaan (Y) Sebagai variabel dependen.

\section{Uji Asumsi Klasik}

\section{Uji Normalitas}

Uji normalitas dilakukan untuk mengetahui apakah data yang digunakan memiliki distribusi normal. Pengujian normalitas dilakukan dengan menggunakan P-P Plot Test. Pengujian normalitas dapat dideteksi dengan melihat penyebaran data (titik) pada sumbu diagonal dari grafik distribusi normal, dan hasilnya dapat dilihat pada Gambar 1 berikut :

\section{Gambar 1}

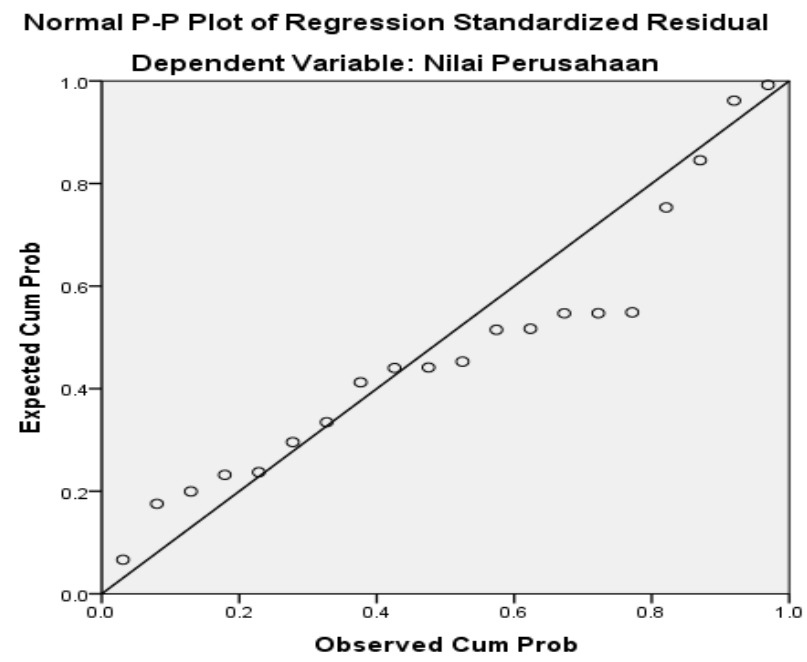

Berdasarkan hasil uji normalitas, dapat dilihat dari Gambar 1 diatas (Normal P-Plot of Regression Standardized Residual) terlihat bahwa titik-titik menyebar di sekitar garis diagonal, serta penyebarannya mengikuti garis diagonal. Hal ini menunjukan bahwa model regresi layak dipakai karena memenuhi asumsi normalitas data berdistribusi normal, karena titik dalam gambar menyebar di sekitar garis diagonal dan arahnya mengikuti garis diagonal.

\section{Uji Heteroskedasitas}

Uji Heteroskedasitas bertujuan untuk menguji apakah dari model regresi terjadi ketidaksamaan varians dari residual satu pengamatan ke pengamatan yang lain. Model regresi yang memenuhi persyaratan adalah dimana terdapat kesamaan varians dari residual satu pengamatan ke pengamatan yang lain tetap atau disebut homoskedastisitas. Model regresi yang baik adalah yang homoskedasitas atau tidak terjadi heteroskedasitas. Salah satu cara mendeteksi ada atau tidaknya heteroskedasitas adalah dengan melihat grafik scatterplot antara lain prediksi variabel terikat dengan residualnya. Jika ada pola tertentu, seperti titik-titik menyebar di atas dan 
di bawah angka 0 pada sumbu Y, maka tidak terjadi heteroskedasitas. Berdasarkan hasil pengolahan data, uji heteroskedasitas dalam penelitian ini ditunjukan pada Gambar 2 berikut :

\section{Gambar 2}

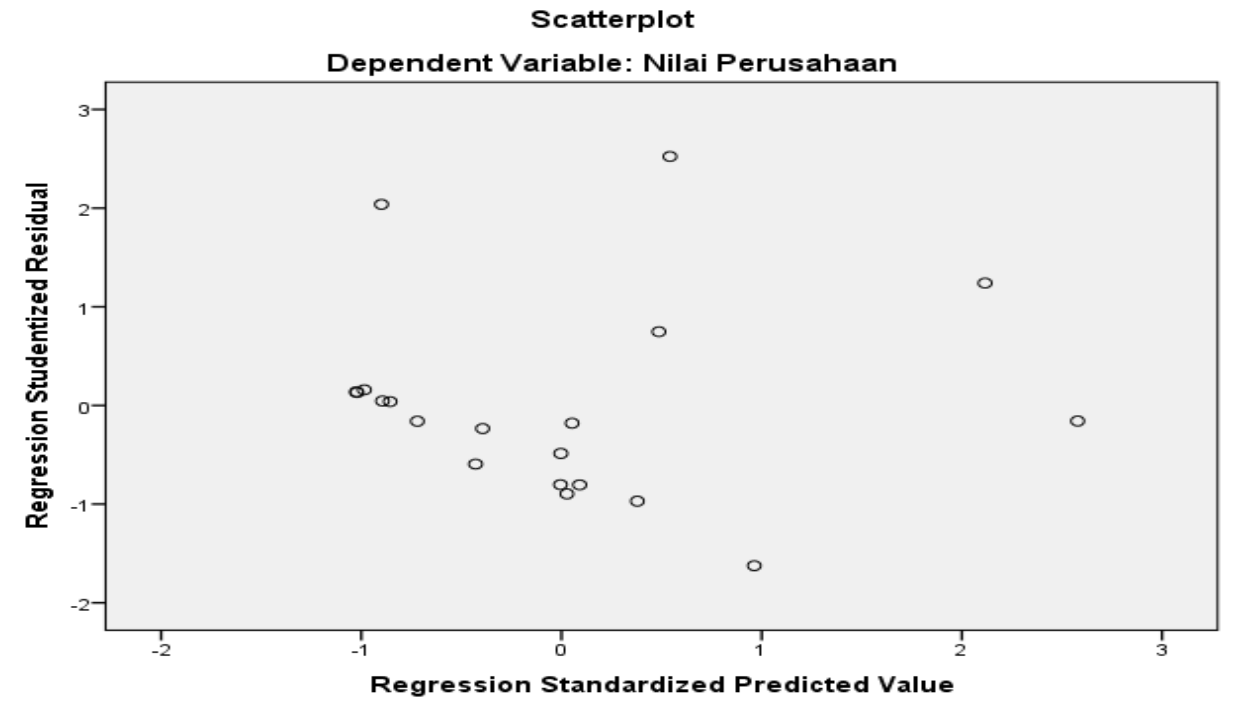

Berdasarkan Gambar 2 menunjukkan bahwa grafik scatterplot terlihat bahwa titik-titik menyebar secara acak serta tersebar baik diatas maupun dibawah angka 0 pada sumbu Y dan titik tidak membentuk suatu pola tertentu, oleh karena itu dapat disimpulkan bahwa variable independen yaitu return on asset, return on equity, dan net profit margin dalam penelitian ini tidak terjadi heteroskedasitas.

Uji Multikolinearitas
Multikolinearitas merupakan fenomena adanya korelasi yang sempurna antara satu variabel bebas dalam suatu model regresi linear berganda. Uji ini dilakukan dengan menggunakan VIF dengan kriteria, jika VIF suatu variabel bebas $>10$, maka dapat disimpulkan bahwa variabel bebas tersebut terjadi multikolinearitas. Berdasarkan hasil analisis regresi linear berganda yang telah dilakukan, ternyata diperoleh nilai VIF masing-masing variabel bebas sebagai berikut :

Tabel 6

Uji Multikolinearitas

\begin{tabular}{|l|r|r|}
\hline \multirow{2}{*}{ Model } & \multicolumn{2}{|c|}{ Collinearity Statistics } \\
\cline { 2 - 3 } & Tolerance & VIF \\
\hline Return On Asset & .173 & 5.797 \\
\hline Return On Equity & .277 & 3.605 \\
\hline Net Profit Margin & .389 & 2.569 \\
\hline
\end{tabular}

Sumber: data olahan 
Berdasarkan Tabel 6 hasil uji multikolinearitas di atas dapat diketahui bahwa nilai VIF dari variabel independen yaitu Return On Asset sebesar 5,797, Return On Equity sebesar 3,605, dan Net Profit Margin sebesar 2,569. Tiga variabel independen tersebut menunjukan nilai tidak lebih dari 10. Oleh karena itu dapat disimpulkan bahwa tidak ada multikolinearitas antara variabel independen dalam model regresi.

\section{Uji Autokorelasi}

Uji Autokorelasi digunakan untuk menguji atau melihat apakah dalam suatu model regresi linear ada korelasi antara suatu periode $\mathrm{t}$ dengan periode sebelumnya (t-1). Durbin Watson (DW) pendeteksian ada tidaknya gejala autokorelasi adalah sebagai berikut. Jika angka DW dibawah -2 berarti ada autokorelasi negatif, sedangkan angka DW diantara -2 sampai 2 berarti tidak terjadi autokorelasi dan jika angka DW diatas +2 berarti ada autokorelasi positif. Berdasarkan hasil perhitungan analisis data dengan menggunakan spss versi 20 diperoleh hasil uji autokorelasi dapat dilihat pada tabel berikut:

Tabel 7

Model Summary

\begin{tabular}{|c|r|r|r|r|r|}
\hline Model & R & R Square & $\begin{array}{c}\text { Adjusted R } \\
\text { Square }\end{array}$ & $\begin{array}{c}\text { Std. Error of the } \\
\text { Estimate }\end{array}$ & Durbin-Watson \\
\hline 1 & $.661^{\mathrm{a}}$ & .438 & .332 & .8172592 & 1.980 \\
\hline
\end{tabular}

Sumber: data olahan

Tabel 7 di atas dapat dilihat nilai DW adalah sebesar 1,980 ini berarti dengan melihat kriteria pengambilan keputusan, maka dapat disimpulkan dalam model regresi tidak terjadi autokorelasi karena nilainya berada diantara -2 dan 2 .

\section{Regresi Linear Berganda}

Analisis data ini menggunakan software spss versi 20 dengan menggunakan data dari laporan keuangan perusahaan dari tahun 2012 - 2016. Hasil pengelolaan tersebut dapat dilihat pada Tabel 8 dibawah ini:

Tabel 8

Coefficients $^{\text {a }}$

\begin{tabular}{|ll|r|r|r|}
\hline \multirow{2}{*}{ Model } & \multicolumn{2}{|c|}{ Unstandardized Coefficients } & Standardized Coefficients \\
\cline { 2 - 4 } & \multicolumn{1}{|c|}{ B } & Std. Error & \multicolumn{1}{c|}{ Beta } \\
\hline \multirow{2}{*}{ (Constant) } & $-2.296 \mathrm{E}-011$ & .183 & \\
1 & .055 & .451 & .055 \\
Return On Asset & -.100 & .356 & -.100 \\
& Return On Equity & .641 & .301 & .641 \\
\hline
\end{tabular}

Sumber: data olahan

Tabel 8 hasil pengolahan data maka dapat dilihat nilai-nilai koefisien seperti pada tabel diatas. Dari nilai koefisien tersebut didapatkan 
persamaan regresi linear sebagai

berikut:

$\mathrm{Y}=-2,296 \times 10^{-011}+0,055 \mathrm{X}_{1}-$ $0,100 X_{2}+0,641 X_{3}+e$

Keterangan: $\mathrm{Y}=$ Nilai Perusahaan; $\mathrm{X}_{1}$ = Return On Asset (ROA); $\mathrm{X}_{2}=$ Return On Equity (ROE); dan $\mathrm{X}_{3}=$ Net Profit Margin (NPM)

Berdasarkan persamaan regresi linear berganda diatas dapat di interprestasikan sebagai berikut:

1. Nilai konstanta sebesar $-2,296 \mathrm{x}$ $10^{-011} 162,248$ memberikan arti bahwa apabila $\left(\mathrm{X}_{1}\right)$ Return On Asset, $\left(\mathrm{X}_{2}\right)$, Return On Equity dan $\left(\mathrm{X}_{3}\right) \quad$ Net Profit Margin diasumsikan $=0$, maka Nilai Perusahaan (Y) akan mengalami penurunan sebesar $-2,296 \times 10^{-}$ $011 \%$.

2. Return On Asset $\left(\mathrm{X}_{1}\right)$ sebesar 0,055, artinya apabila variabel Return On Asset mengalami kenaikan sebesar $1 \%$ sedangkan variabel lainnya dianggap konstan, maka variabel dependen yaitu nilai perusahaan akan mengalami peningkatan sebesar $0,055 \%$
3. Return On Equity $\left(\mathrm{X}_{2}\right)$ sebesar 0,100, artinya apabila variabel Return On Equity mengalami kenaikan sebesar $1 \%$ sedangkan variabel lainnya dianggap konstan, maka variabel dependen yaitu nilai perusahaan akan mengalami penurunan sebesar $-0,100 \%$.

4. Net Profit Margin $\left(\mathrm{X}_{3}\right)$ sebesar 0,641 , artinya apabila variabel $\mathrm{Net}$ Profit Margin mengalami kenaikan sebesar $1 \%$ sedangkan variabel lainnya dianggap konstan, maka variabel dependen yaitu nilai perusahaan akan mengalami peningkatan sebesar $0,641 \%$.

\section{Uji Statistik}

Uji Hipotesis Secara Simultan (Uji F)

Uji simultan digunakan untuk mengetahui apakah variabel independen secara simultan mempengaruhi variabel dependen. Berikut hasil uji $F$ yang diolah menggunakan spss 20 disajikan dalam tabel dibawah ini :

Tabel 9

ANOVA

\begin{tabular}{|ll|r|r|r|r|l|}
\hline \multicolumn{1}{|c|}{ Model } & Sum of Squares & \multicolumn{1}{c|}{ df } & Mean Square & F & Sig. \\
\hline \multirow{3}{*}{1} & Regression & 8.313 & 3 & 2.771 & 4.149 & $.024^{\mathrm{b}}$ \\
Residual & 10.687 & 16 & .668 & & \\
\cline { 2 - 5 } & 19.000 & 19 & & & \\
\hline
\end{tabular}

Sumber: data olahan

Hasil perhitungan menggunakan program spss dengan membandingkan $f_{\text {hitung dengan }} f_{\text {tabel }}$ dengan taraf signifikan a $=0,05$. Dapat diketahui bahwa $f_{\text {hitung }}$ sebesar 4,149 dengan membandingkan $\mathrm{f}_{\text {tabel }} \mathrm{a}=0,05$ dengan derajat bebas pembilang 3 dan derajat penyebutnya 16 , didapat $\mathrm{f}_{\text {tabel }}$ sebesar 3,24 . Dari hasil tersebut terlihat bahwa fitung lebih besar dari

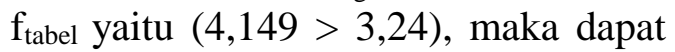
disimpulkan bahwa $\mathrm{H}_{\mathrm{a}}$ diterima artinya secara simultan variabel independen rasio profitabilitas berpengaruh signifikan terhadap variabel dependen nilai perusahaan.

Uji $t$ 
Pengujian ini dilakukan untuk mengetahui tingkat signifikan pengaruh masing-masing variabel independen terhadap variabel dependen dengan menguji koefesien variabel tersebut, pada perusahaan minyak dan gas bumi yang terdaftar di Bursa Efek Indonesia periode 2012 2016. Berdasarkan pada Tabel 8 diatas hasil pengujian secara parsial dapat dijelaskan sebagai berikut :

- Nilai thitung variabel return on asset sebesar 0,122 dan $t_{\text {tabel }}$ sebesar 2,120 dari hasil perbandingan maka dapat diketahui thitung lebih kecil dari $t_{\text {tabel}},(0,122<2,120)$. Maka Ho diterima dan Ha ditolak artinya secara parsial variabel return on asset tidak berpengaruh signifikan terhadap variabel dependen nilai perusahaan.

- Nilai thitung variabel return on equity sebesar -0,280 dan $t_{\text {tabel }}$ sebesar 2,120 dari hasil perbandingan maka dapat diketahui thitung lebih kecil dari

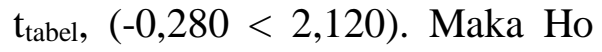
diterima dan $\mathrm{Ha}$ ditolak artinya secara parsial variabel return on equity tidak berpengaruh signifikan terhadap variabel dependen nilai perusahaan.

- Nilai thitung variabel net profit margin sebesar 2,131 dan $t_{\text {tabel }}$ sebesar 2,120 dari hasil perbandingan maka dapat diketahui thitung lebih besar dari $t_{\text {tabel, }}(2,131>2,120)$. Maka Ho ditolak dan $\mathrm{Ha}$ diterima artinya secara parsial variabel net profit margin berpengaruh signifikan terhadap variabel dependen nilai perusahaan.

\section{Koefisien Determinasi $\left(R^{2}\right)$}

Uji koefisien determinasi digunakan untuk mengukur seberapa jauh kemampuan model dalam menerangkan variasi variabel independen terhadap variabel dependen. Berdasarkan hasil pada Tabel 7 bahwa pengujian koefisien determinasi pada tabel diatas, menunjukkan bahwa nilai $\mathrm{R}$ Square sebesar 0,438 yang artinya bahwa variabilitas variabel dependen yang dapat dijelaskan oleh variabel independen rasio profitabilitas yang diwakili oleh return on asset, return on equity, dan net profit margin dalam penelitian ini adalah sebesar 43,8\%, sedangkan sisanya $56,2 \%$ dijelaskan oleh variabel-variabel lain di luar model penelitian. Penelitian ini dilakukan dengan menggunakan sampel penelitian dari 4 perusahaan yang termasuk industri minyak dan gas bumi yang terdaftar di Bursa Efek Indonesia periode 2012 - 2016. Adapun tujuan dari penelitian ini adalah untuk mengukur dan mengetahui seberapa besar pengaruh rasio profitabilitas terhadap nilai perusahaan baik secara simultan ataupun secara parsial pada industri minyak dan gas bumi yang terdaftar di Bursa Efek Indonesia (BEI) selama periode 2012 - 2016.Pengujian hipotesis yang dilakukan terhadap analisis regresi menunjukkan ada tidaknya pengaruh antara variabel independen rasio profitabilitas yang diwakili return on asset, return on equity, dan net profit margin yang di masukkan kedalam model regresi dengan variabel dependen yaitu nilai perusahaan.

\section{Pengaruh Rasio Profitabilitas Terhadap Nilai Perusahaan Secara Simultan \\ Berdasarkan hasil secara simutan seluruh variabel bebas berpengaruh signifikan terhadap}


variabel terikat pada $\alpha=5 \%$ atau 0,05 dan kriteria uji $\mathrm{F}$ dengan membandingkan $F_{\text {hitung }}$ sebesar 4,149 dan $F_{\text {tabel }}$ sebesar 3,24, maka dapat dilihat bahwa $F_{\text {hitung }}>F_{\text {tabel }}$ yaitu 4,149 $>3,24$, artinya terdapat pengaruh signifikan antara variabel independen rasio profitabilitas yang diwakili return on asset, return on equity, dan net profit margin secara simultan terhadap nilai perusahaan pada industri minyak dan gas bumi periode 2012 2016. Hasil penelitian ini didukung oleh penelitian sebelumnya yaitu penelitian yang lakukan oleh Dewanto (2017:11) yang menunjukkan hasil bahwa return on asset, return on equity, dan net profit margin berpengaruh signifikan terhadap nilai perusahaan.

\section{Pengaruh Return On Asset Terhadap Nilai Perusahaan Secara Parsial}

Berdasarkan nilai thitung variabel return on asset sebesar 0,122 dan $t_{\text {tabel }}$ 2,120 dari hasil perbandingan maka dapat diketahui $t_{\text {hitung }}<\mathrm{t}_{\text {tabel }}(0,122<$ 2,120). Dapat dilihat dari signifikan return on asset sebesar 0,904 lebih besar dari $\alpha=0,05$. Maka Ho diterima Ha ditolak artinya tidak ada pengaruh signifikan return on asset secara parsial terhadap nilai perusahaan pada industri minyak dan gas bumi periode 2012 - 2016. Kemungkinan hal ini dikarenakan terdapat faktor lain yang lebih besar pengaruhnya terhadap nilai perusahaan. Hasil penelitian ini sejalan dengan penelitian sebelumnya yaitu penelitian yang lakukan oleh Dewanto (2017 : 13) pada industri makanan dan minuman yang terdaftar di Bursa Efek Indonesia periode 2010-2014 yang menujukkan return on asset tidak mempunyai pengaruh signifikan terhadap nilai perusahaan.
Hasil penelitian ini tidak sejalan dengan penelitian yang dilakukan oleh syamsudin (2009:16) yang menyatakan terdapat pengaruh positif antara return on asset terhadap nilai perusahaan. Dimana ia menyatakan semakin tinggi nilai return on asset suatu perusahaan, maka perusahaan itu akan meningkatkan kepercayaan investor untuk memiliki saham perusahaan tersebut dan dalam kondisi ini perusahaan akan menaikkan harga saham dan kenaikan harga saham akan mempengaruhi nilai perusahaan.

\section{Pengaruh Return On Equity Terhadap Nilai Perusahaan Secara Parsial}

Dari nilai thitung variabel return on equity $-0,280$ dan $t_{\text {tabel }} 2,120$ dari hasil perbandingan maka dapat diketahui $t_{\text {hitung }}<\mathrm{t}_{\text {tabel }}(-0,280<2,120)$. Dapat dilihat dari signifikan return on equity sebesar 0,783 lebih besar dari $\alpha$ $=0,05$. Maka Ho diterima dan $\mathrm{Ha}$ ditolak artinya tidak ada pengaruh signifikan return on equity secara parsial terhadap nilai perusahaan pada industri minyak dan gas bumi periode 2012 - 2016. Hal ini berarti dari total modal yang ada tidak mempengaruhi nilai perusahaan. Dengan jumlah equity yang tinggi maka mengakibatkan banyak dana yang kurang produktif sehingga perlu adanya pengalokasian dana yang dapat menghasilkan keuntungan, seperti memperluas lahan usaha atau menambah peralatan pabrik.

Hasil penelitian ini sejalan dengan penelitian sebelumnya yaitu penelitian yang lakukan Putri (2013:17) pada perusahaan manufaktur sub-sektor otomotif di Bursa Efek Indonesia periode 2010-2012 yang menunjukkan hasil bahwa return on 
equity tidak berpengaruh signifikan terhadap nilai perusahaan.

\section{Pengaruh Net Profit Margin Terhadap Nilai Perusahaan Secara Parsial}

Nilai $t_{\text {hitung }}$ variabel net profit margin 2,131 dan tabel sebesar 2,120 dari hasil perbandingan maka dapat diketahui $t_{\text {hitung }}>\mathrm{t}_{\text {tabel }}(2,131>2,120)$. Dapat dilihat dari signifikan net profit margin sebesar 0,049 lebih kecil dari $\alpha$ $=$ 0,05. Maka Ho ditolak dan $\mathrm{Ha}$ diterima artinya terdapat pengaruh signifikan variabel net profit margin secara parsial terhadap nilai perusahaan pada industri minyak dan gas bumi periode 2012 - 2016. Ini menunjukkan semakin ringgi net profit margin suatu perusahaan, maka perusahaan itu akan meningkatkan kepercayaan investor untuk memiliki saham perusahaan tersebut dan dalam kondisi ini perusahaan akan menaikkan harga saham dan kenaikan harga saham akan mempengaruhi nilai perusahaan.

Hasil penelitian ini sejalan dengan penelitian sebelumnya yaitu penelitian yang lakukan Putri (2013:17) pada perusahaan manufaktur sub-sektor otomotif di Bursa Efek Indonesia (BEI) periode 2010 - 2012 yang menunjukkan hasil bahwa net profit margin berpengaruh positif terhadap nilai perusahaan. Namun penelitian ini tidak sejalan dengan penelitian sebelumnya yaitu penelitian yang lakukan oleh Dewanto (2017:14) pada industri makanan dan minuman yang terdaftar di Bursa Efek Indonesia (BEI) periode $2010 \quad-2014$ yang menunjukkan hasil bahwa net profit margin tidak mempunyai pengaruh signifikan terhadap nilai perusahaan.

\section{Hubungan Antar Variabel Independen dan Dependen}

Berdasarkan hasil pengujian koefisien determinasi, menunjukkan bahwa nilai $\mathrm{R}$ Square sebesar 0,438 yang artinya bahwa variabilitas variabel dependen yang dapat dijelaskan oleh variabel independen yaitu return on asset, return on equity, dan net profit dalam penelitian ini adalah sebesar 43,8\%, sedangkan sisanya $56,2 \%$ dijelaskan oleh variabel-variabel lain di luar model penelitian yang digunakan.

\section{SIMPULAN}

Berdasarkan hasil penelitian, maka kesimpulan dalam penelitian ini adalah:

1. Hasil pengujian secara simultan menunjukkan model regresi secara simultan diperoleh nilai signifikan sebesar $0,024<0,05$ (taraf signifikasi). Selain itu dapat dilihat juga dilihat hasil perbandingan antara $f_{\text {hitung }}$ dan $f_{\text {tabel }}$ yang menunjukan $f_{\text {hitung }}$ sebesar 4,149, sedangkan $\mathrm{f}_{\text {tabel }}$ sebesar 3,24. Dari hasil tersebut terlihat bahwa $\mathrm{f}_{\text {hitung }}>\mathrm{f}_{\text {tabel }}$ yaitu $4,149>$ 3,24, maka dapat disimpulkan bahwa secara simultan variabel independen rasio profitabilitas yang diwakili oleh return on asset, return on equity, dan net profit margin berpengaruh signifikan terhadap variabel dependen nilai perusahaan pada industri minyak dan gas bumi periode 2012 2016.

2. Hasil pengujian pada model regresi secara parsial nilai thitung variabel return on asset sebesar 0,122 dan $t_{\text {tabel }} 2,120$ dari hasil perbandingan maka dapat diketahui $t_{\text {hitung }}<\mathrm{t}_{\text {tabel }}(0,122<$ 2,120). Dapat dilihat dari 
signifikan return on asset sebesar 0,904 lebih besar dari $\alpha=0,05$. Maka Ho diterima $\mathrm{Ha}$ ditolak artinya tidak ada pengaruh signifikan return on asset secara parsial terhadap nilai perusahaan. Dengan demikian, hasilnya tidak dapat digunakan untuk menunjukkan bahwa return on asset dapat mempengaruhi nilai perusahaan. Dari hasil perbandingan antara nilai thitung variabel return on equity $-0,280$ dan $t_{\text {tabel }} 2,120$ dari hasil perbandingan maka dapat diketahui $\mathrm{t}_{\text {hitung }}<\mathrm{t}_{\text {tabel }}(-0,280<$ 2,120). Dapat dilihat dari signifikan return on equity sebesar 0,783 lebih besar dari $\alpha=0,05$. Maka Ho diterima dan Ha ditolak artinya tidak ada pengaruh signifikan return on equity secara parsial terhadap nilai perusahaan. Sedangkan hasil uji t (parsial) pada model regresi net profit margin perbandingan antara nilai $t_{\text {hitung variabel net profit margin }}$ 2,131 dan tabel sebesar 2,120 dari hasil perbandingan maka dapat diketahui $t_{\text {hitung }}>t_{\text {tabel }}(2,131>$ 2,120). Dapat dilihat dari signifikan net profit margin sebesar 0,049 lebih kecil dari $\alpha=$ 0,05. Maka Ho ditolak dan Ha diterima artinya terdapat pengaruh signifikan variabel net profit margin secara parsial terhadap nilai perusahaan pada industri minyak dan gas bumi periode 2012 - 2016.

3. Berdasarkan pengujian koefisien determinasi menunjukkan bahwa $\mathrm{R}$ Squre sebesar 0,438 yang artinya bahwa variabilitas variabel dependen yang dapat dijelaskan oleh variabel independen yaitu return on asset, return on equity, dan net profit margin dalam penelitian ini sebesar $43,8 \%$ sedangkan sisanya $56,2 \%$ dijelaskan oleh variabel lain diluar model penelitian.

4. Berdasarkan penelitian ini, variabel independen yang dominan mempengaruhi nilai perusahaan ialah net profit margin.

\section{DAFTAR PUSTAKA}

Bastian, Indra dan Suhardjono (2006), Akuntansi Perbankan, Edisi 1, Jakarta : Salemba Empat.

Dewanto, Alfret K. (2017), Jurnal, : Pengaruh Rasio Laverage dan Profitabilitas terhadap Nilai Perusahaan Industri Makanan dan Minuman yang Terdaftar di Bursa Efek Indonesia, Universitas Tadulako, Palu

Fahmi, Irham (2014), Manajemen Keuangan Perusahaan dan Pasar Modal, Edisi pertama, Jakarta: Mitra Wacana Media.

$$
\text { (2016), Pengantar }
$$

Manajemen Keuangan Teori

Dan Soal Jawab, Cetakan kelima, Bandung: Alfabeta.

Husnan, Suad dan Enni Pudjiastuti (2004),

Dasar-dasar Manajemen Keuangan, Edisi 4, Yogyakarta : UPP AMP YKPN.

Istijanto (2009), Aplikasi Praktis Riset Pemasaran, Jakarta : Gramedia Pustaka Utama.

Ningrum, Arista Kencana (2010), Jurnal : Pengaruh Minat Belajar dan Kepedulian Orangtua Terhadap Prestasi Belajar Siswa Kelas VII SMP Negri 2 Getak Sukaharjo Tahun Ajaran 2010/2011", UMS, Surakarta.

Novianto, Nico Hernanto (2016), Jurnal : Pengaruh Profitabilitas 
dan Pertumbuhan Perusahaan

Terhadap Nilai Perusahaan

Dengan Struktur Modal

Sebagai Variabel Mediating

pada Perusahaan Manufaktur

di Bursa Efek Indonesia UNTAR, Jakarta.

Putri, Cintami Prananti (2013), Jurnal : Analisis Pengaruh Rasio Profitabilitas Terhadap Nilai Perusahaan Manufaktur SubSektor Otomotif dan Komponen di Bursa Efek Indonesia, UNESA, Surabaya.

Riyanto, Bambang (2010), Dasardasar pembelian perusahaan, Jakarta : BPFE

Syamsudin, Lukman (2009), Manajemen Keuangan Perusahaan, Jakarta : PT. Raja Grafindo Persada.

Syekh, Sayid (2011), Pengantar Statistik Ekonomi dan Sosial, Jakarta : GP. Press 